Volume 13 Number 2, April-June 2019: pp. 167-186. Copyright (c) 2019 FIAT JUSTISIA. Faculty of Law, Lampung University, Bandarlampung, Lampung, Indonesia. ISSN: 1978-5186 | e-ISSN: 2477-6238.Open Access: http://jurnal.fh.unila.ac.id/index.php/fiat

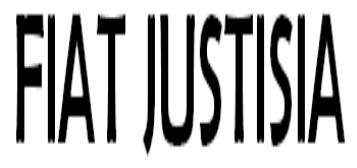

Fiat Justisia is licensed under a Creative Commons Attribution 4.0 International License, which permits unrestricted use, distribution, and reproduction in any medium, provided the original work is properly cited.

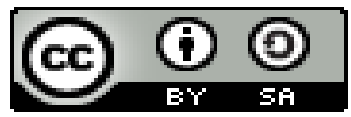

\title{
The Accommodation of ASEAN Convention against Trafficking in Persons (ACTIP) in Indonesia Regulation
}

\author{
Jevlin Solim \\ Prima University of Indonesia, Indonesia \\ jevlinsolimm@gmail.com
}

\begin{abstract}
Trafficking in Persons is unarguably one of the largest crime industries in the $21^{\text {st }}$ century that demand a concrete and comprehensive approach to prevent and tackle it. Southeast Asia region is one of the highest regions in terms of supplying, transit, and destination for trafficking in persons victims in the world. ASEAN member states, including Indonesia as key sources of trafficking victims have taken many efforts, one of the latest was ratifying ASEAN Convention Against Trafficking in Persons, Especially Women and Children (ACTIP). And to ensure its effectiveness, the parties need to adjust it with the domestic laws. However, almost 2 years since the ratification, it can hardly be identified any new regulations specifically formed to combat TIPs being enacted to support this convention in Indonesia. Therefore, the objective of this journal is to give insights about the accommodation ACTIP in Indonesia regulation.
\end{abstract}

Keywords: Trafficking, ACTIP, ASEAN Convention, and Indonesia

How to Cite: Jevlin Solim, "The Accommodation of ASEAN Convention against Trafficking in Persons (ACTIP) in Indonesia Regulation", Fiat Justisia, 13 (2), (2019).

DOI: https://doi.org/10.25041/fiatjustisia.v13no2.1680 


\section{A. Introduction}

Trafficking in Persons (TIPs) has become a global agenda in law enforcement and gained international attention as the impact is widely disruptive. It has been a serious threat to societies, nations, and countries around the world as it deeply violates human rights norms and offenses the dignity of human beings. TIPs can be categorized as organized crime, white collar crime, corporate crime, cybercrime, and even transnational crime as the scope and dimension have broadened through centuries. ${ }^{1}$ This practice has been around since the ancient era, it can be seen from the practice of slavery and has developed through time. As reported by United Nations (UN) and International Labour Organization (ILO), TIPs is the third largest crime and one of the most lucrative crime industries in the world (estimated illicit profits exceeding US\$ 150 billion annually) ${ }^{2}$ as it tightly correlates with money laundering, people smuggling, and illegal drug trade. A report released by the International Labor Organization (ILO) and Walk Free Foundation estimated there were 40.3 million victims of modern slavery in 2016 with one in every four victims were children below the age of $18 .{ }^{3}$ Furthermore, UN has estimated no less than 4 million people have been victims of trafficking every year, among those women and children make up the largest proportions, and within this number, around 600-800 thousand people are trafficked globally cross the international border areas.

Indonesia as the fourth most populous nation in the world with over 250 million population has become a key source, as well as transit, and destination country for TIPs victims that are being imposed to force labor and sex trade. It is estimated no less than 80 thousand women and children are being exploited for sexual purpose each year. Meanwhile, the men victims are sent to regions for forced labor in various ventures, like mining, plantations, and constructions. ${ }^{4}$ The underlying motives of TIPs are different from one country to another and widely varied, from economic instability, socio-cultural, highmaintenance lifestyle, lack of job opportunities, gender inequality (patrilineal hierarchy system), politics and conflicts, inefficient legal systems, government corruption, national and regional securities issues, to demand that cultivate all types of human trafficking, as well as the exposure to the

\footnotetext{
${ }^{1}$ Henny NuraenyTindak Pidana Perdagangan Orang Kebijakan Hukum Pidana dan Pencegahannya, Jakarta: Sinar Grafika, (2011), p.275.

${ }^{2}$ Trajano Julius Cesar, "Combating Human Trafficking in East Asia: Mind the Gaps", NTS Insight Singapore, 18 (05), (2018), p.2.

${ }^{3}$ ILO and Walk Free Foundation, (2017), Global Estimates of Modern Slavery, Geneva: International Labor Office, p.5.

${ }^{4}$ IOM Local X and USAID, Human Trafficking Snapshot Indonesia, Jakarta: IOM Stop Exploitation, (2018), p.6.
} 
globalization has also increased people's vulnerability to trafficking as it changes people's expectations, particularly the youth. ${ }^{5}$

As one of the most vulnerable country to TIPs, Indonesia must take lots of efforts regarding prevention and eradication of TIPs practice, as well as the protection and rehabilitation of the victims. Indonesia has been involved in numerous conferences, forums, and organizations, both on regional and international level, either as initiator or participant to combat trafficking. On the international scale, Indonesia is actively engaged in lots of United Nations Convention on Transnational Organized Crime (UNTOC) agenda and has ratified the Palermo Convention as well as its Protocol to Prevent, Suppress, and Punish TIPs, especially Women and Children, Supplementing the UNTOC. In 2013, Indonesia started Bali Process along with Australia launched a Special Conference on Irregular Movement of Persons which subsequently hold various Meeting and Workshop. Furthermore, to maximalize the prevention and control, Indonesia has released many laws and regulations related to TIPs. Besides, the government has established an integrated service centre for women's empowerment and children (Pusat Pelayanan Terpadu Pemberdayaan Perempuan dan Anak/ P2TP2A) in 33 provinces and/or 247 cities/districts across. ${ }^{6}$

On the regional scale, the prevention and elimination attempt of TIPs are being executed through the ASEAN $^{7}$ cooperation. Since the early 1990s, ASEAN has discussed and put extra attention on Transnational Organized Crime, later including TIPs issues. One of the attempts is ASEAN has developed the ASEAN MLAT that can provide mechanism through which the countries in ASEAN territory can appeal and support one another in the solicitation of data, proof, and testimony for the investigation and criminal proceedings ${ }^{8}$ to aid and expedite the attempts to eliminate TOCs in the region. Furthermore, many meetings have been organized and quite lots of legal instruments regarding this matter have been made, for instance, the ASEAN Declaration Against TIPs, Particularly Women and Children (2004), the Leader's Joint Statement on Enhancing Cooperation Against Trafficking in Persons in South East Asia (2011), ASEAN Human Rights Declaration

\footnotetext{
5 Absor Ulli M., "Human Trafficking and The Challenges for Social Development in Indonesia", Jurnal Pemikiran Sosiologi, 5 (1), (2019). p.45.

${ }^{6}$ Sekertariat GT-PPTPPO, Pencegahan dan Penanganan Tindak Pidana Perdagangan Orang Laporan 2015, Indonesia: Kementrian Pemberdayaan dan Perlindungan Perempuan dan Anak Republik Indonesia, (2015), pp.21-31.

${ }^{7}$ A regional intergovernmental organization established on $8^{\text {th }}$ August 1967 in Bangkok; it consists of Indonesia, Thailand, Malaysia, Singapore, The Philippines, Brunei Darussalam, Vietnam Lao PDR, Myanmar, and Cambodia.

${ }^{8}$ Pauline David, Fiona David, and Anne Gallagher, ASEAN Handbook on International Legal Cooperation in Trafficking in Persons Cases, Jakarta: ASEAN Secretariat, (2010), p.26.
} 
(2012) ${ }^{9}$, and the latest ASEAN Convention Against TIPs, Especially Women and Children/ ACTIP (2017). This convention is being proposed as ASEAN member states realize that they share obligation and generic ambition to avert, indict and penalize TIPs perpetrators, protect and assist victims of TIPs yet there were not any regional regulations, specifically designed to eradicate TIPs practice that were effective and cogent. The general idea behind this convention is to establish a regional instrument that specifically deals with TIPs and is legally binding, as well as standardize the conception of TIPs, enhance the prevention, protection, law enforcement, intensifies the coordination and cooperation among authorities to eradicate TIPs in the region. The efforts to eliminate TIPs through ACTIP ratification is being mandated in the blueprint of ASEAN Political and Security Community, "Ensure the early ratification of the ASEAN Convention Against Trafficking in Persons Particularly Women and Children, and its effective implementation, as well as carry out the ASEAN Plan of Action Against Trafficking in Persons Particularly Women and Children." ${ }^{10}$ Furthermore, this convention would assist ASEAN member states, despite whether they are states of source, transit, or destination, to engange with their divergent domestic priorities, threats, and policies to eradicate TIPs practice..$^{11}$ The main objective of this convention is to actualize the concept of 4Ps, Protection, Prevention, Prosecution, and Partnership through the cooperation within ASEAN member states. ${ }^{12}$

Indonesia ratified this convention in 2017 through the Law No. 12 of 2017 to show commitment and fulfill the moral duty as part of the signatory states. However, the fundamental reason behind the ratification is due to its alignment with the national purpose as stated in First and Fourth Alinea of the Preamble of the 1945 Constitution of the Republic of Indonesia ${ }^{13}$, First Alinea stated "Bahwa sesungguhnya kemerdekaan itu adalah hak segala bangsa dan oleh sebab itu maka penjajahan diatas dunia harus dihapuskan, karena tidak sesuai dengan peri kemanusiaan dan perikeadilan". While the Fourth Alinea, stated "Kemudian daripada itu untuk membentuk suatu Pemerintah Negara Republik Indonesia yang melindungi segenap bangsa Indonesia dan seluruh tumpah darah Indonesia, dan untuk memajukan kesejahteraan umum, mencerdaskan kehidupan bangsa dan ikut melaksanakan ketertiban dunia, yang berdasarkan kemerdekaan perdamaian abadi, dan keadilan sosial, maka

\footnotetext{
${ }^{9}$ Kementerian Hukum dan HAM Republik Indonesia, Naskah Akademis RUU Tentang Pengesahan ACTIP, Jakarta, (2016), p.1-2.

${ }^{10}$ ASEAN, ASEAN Political-Security Community Blueprint 2025, Jakarta: ASEAN Secretariat, (2016), p.19.

11 The Preamble of ACTIP.

12 Akbar, Norvan, Indonesia Meratifikasi Konvensi ASEAN Anti-Perdagangan Orang, https://jpp.go.id/polkam/hukum/311972-indonesia-meratifikasi-konvensi-anti-perdaganganorang-asean, 11 April 2019.

${ }^{13}$ Kementerian Hukum dan HAM Republik Indonesia, Op.Cit., pp.3-4.
} 
disusunlah kemerdekaan kebangsaan Indonesia itu dalam suatu UndangUndang Dasar Negara Indonesia, yang terbentuk dalam suatu susunan negara Republik Indonesia yang berkedaulatan rakyat dengan berdasar pada: Ketuhanan Yang Maha Esa, Kemanusiaan yang adil dan beradab, Persatuan Indonesia, dan Kerakyatan yang dipimpin oleh hikmat kebijaksanaan dalam permusyawaratan/perwakilan, serta dengan mewujudkan suatu keadilan sosial bagi seluruh rakyat Indonesia." This Preamble clearly shows Indonesia 5 basic values, which are Godhead, Humanity, Unity, and Justice Value. The value that being highlights in the ratification of ACTIP convention is the Value of Humanity which implies that all Indonesian people must be treated with respect and treat other human beings with respect, uphold moral values and living together as a society based on the conscience. ${ }^{14}$

The convention is believed to complete and help other existing laws regarding TIPs in Indonesia (Law No. 21/2007 concerning The Eradication of The Criminal Act of Trafficking in Persons) and hopefully it can strengthen as well as enhance the coordination within the ASEAN member states on TIPs issues. Based on the circumstances above, ACTIP can be regarded as a breakthrough instrument to combat TIPs regionally. Almost two years since the ratification, any distinctive national legislations specifically designed to combat TIPs still can't be identified yet, though an instrument will necessarily impactful only if it is being well accommodated. Are the existing regulations have sufficiently accommodated the ACTIP? Therefore, the concern that the author wants to discuss further in this journal is how is the accommodation of ACTIP in Indonesia regulation?

\section{B. Method}

The method used in this journal is normative juridical. This approach requires secondary data that usually use in the writing of normative law. The information in this journal is obtain from the review of legal material combined with library research technique for the data compilation.

\section{Analysis and Discussion}

\section{ACTIP}

ACTIP is the manifestation of ASEAN further commitment and continuous efforts to combat TOCs, specifically TIPs in Southeast Asia. Initially, the efforts to combat transnational crime were focused to eradicate illicit drugs trafficking and abuse only, then the region got to work on numerous of advanced patterns of TOCs which have outstrip national frontiers

\footnotetext{
${ }^{14}$ Mokhammad Najih, "Indonesian Penal Policy: Toward Indonesian Criminal Law Reform Based on Pancasila", Journal of Indonesian Legal Studies, 3 (2), (2018), pp. 163-164.
} 
and state jurisdiction, for instance the act of money laundering, terrorism, as well as women and children trafficking. ${ }^{15}$ The very first ASEAN instrument that covers the act of TIPs was ASEAN Declaration on Transnational Crime that was adopted in 1997 at the First ASEAN Conference participated by the ASEAN Ministers of Interior/Home Affairs and the Representatives of the ASEAN Member States. ${ }^{16}$ This declaration basically proclaimed to enhance the efforts on eliminating TOCs and strengthening the coordination and cooperation within member states, as well as agreeing on to form ASEAN Plan of Action to Combat Transnational Crime. ${ }^{17}$ This declaration later on becoming the landmark document for the establishment of several ASEAN institutional frameworks on combatting transnational organized crime, such as the ASEAN Ministerial Meeting on Transnational on Transnational Crime $(\mathrm{AMMTC})^{18}$ and its subsidiary body ASEAN Senior Officials Meeting on Transnational Crime (SOMTC). ${ }^{19}$

In 1999, ASEAN established the ASEAN Plan of Action in Combating Transnational Crime as the manifestation of ASEAN mandate to enhance the efforts in eradicating transnational crime, both generally and exclusively. In general, the ASEAN Member States agreed on to widen their efforts in combatting transnational crime at the national and bilateral stage to the regional level; strengthen the regional pledge and scope to eradicate transnational crimes, that cover illicit drug trade, money laudering, terrorism, weapons smuggling, TIPs, and ship and/or plane hijack. In particular, the ASEAN member countries agreed on to develop strategic legal frameworks to prevent, suppress, and neutralize transnational crimes, expand the cooperation and coordination in law enforcement, including not limited to investigation, prosecution, mutual legal assistance, intelligence sharing, and extradition. ${ }^{20}$

\footnotetext{
15 ASEAN, (2012), ASEAN Documents on Combating Transnational Crime and Terrorism, Jakarta: ASEAN Secretariat, p.18.

16 ASEAN, ASEAN Declaration on Transnational Crime Manila, 20 December 1997, $\mathrm{https}$ ://asean.org/?static_post=asean-declaration-on-transnational-crime-manila-20-december1997, 31 May 2019.

${ }^{17}$ Kementerian Hukum dan HAM Republik Indonesia, Op.Cit., p.23.

18 The highest policy making body on ASEAN cooperation in combatting transnational crime. It also coordinates activities on the relevant bodies, such as the ASEAN Senior Officials on Drug Matters (ASOD), ASEAN Chiefs on National Police (ASEANAPOL), ASEAN DirectorsGeneral of Customs, ASEAN Directors General of Immigration and the Heads of Consular Affairs of the Ministry of Foreign Affairs. It also approves the reports of SOMTC and other relevant bodies reports.

${ }^{19}$ The body that implement policies and plan adopted by AMMTC, develop work programmes as well as designate a national focal point/agency, and promote the cooperation and coordination with other ASEAN bodies relevant to the Transnational Crime, such as ASOD, ASEANAPOL, etc.

${ }^{20}$ Kementerian Hukum dan HAM Republik Indonesia, Op.Cit., p.24.
} 
This Action Plan was the beginning of ASEAN effort to focus on handling the transnational crime within the region.

Finally, in 2004 at the $10^{\text {th }}$ ASEAN High-Level Conference (Konferensi Tingkat Tinggi ASEAN), the Head of States/ Governments approved ASEAN Declaration Against TIPs, Particularly Women and Children which become the pioneer of ACTIP. The declaration proclaimed the exigent neccesity for an extensive and complete regional resolution to impede and eliminate TIPs. This declaration acknowledged that there are lots of factors contribute to the increasing of TIPs, including people migration. Further research done by United Nations Office on Drugs and Crime (UNODC) shown the relevancy and correlated factors that contribute to the expansion of TIPs practice, such as local circumstances encourage citizens to move to improve their life conditions; poverty, the downfall of human rights, inadequacy of social and monetary hope, internal dispute and armed conflict, natural disasters, political imbalance, state riot,public insurrection, etc. ${ }^{21}$ The declaration affirmed 8 main points as the efforts to extend the eradication attempts in ASEAN. The 8 points encourage the establishment of a regional focal network, adopt measures to protect the integrity of travel documents, carry out constant swap of knowledges and ideas, data exchange on compatible migratory stream, restoring and enhancing border commands and supervising the operations and procedures, extend cooperation between concerned immigration and other government officials, distinguish TIPs victims from the offenders, and recognize as well as pinpoint the source countries, etc. ${ }^{22}$

Following this declaration, in 2006 ASEAN released a report named ASEAN's Reports to TIPs focusing on the criminal justice response to examine how far the government of each state has taken the efforts to combat trafficking. The report concluded that TIPs has not been prioritized, lack of understanding, limited resources to combat TIPs, ineffective surveillance regarding migrant workers' work condition, limited national legislation related to TIPs issues, corrupt officials, and etc. This report also gave recommendations to enhance the effectiveness of the country to eliminate TIPs matter, such as the need of vivid blueprint or standard of TIPs, the importance of national action plan specifically designed to deter and eradicate TIPs, the expansion of legislative agenda and extradition as well mutual legal assistance framework to ensnare the syndicates, provide compensation and protect the victims and witness to testify in the criminal court, investigate the involvement of government officials as the main actors of the TIPs enterprise, and increase the borders' security. ${ }^{23}$

${ }^{21}$ UNODC, Toolkit to Combat Trafficking in Persons Global Programme Against Trafficking in Human Beings, Vienna: UNODC Office, (2008), p.454.

${ }^{22}$ ASEAN Declaration Against Trafficking in Persons, Particularly Women and Children.

${ }^{23}$ Kementerian Hukum dan HAM Republik Indonesia, Op.Cit., p.25-26. 
ACTIP was originally discussed for the first time at the $6^{\text {th }}$ AMMTC in Bandar Seri Bengawan, Brunei Darussalam where the member states representatives agree on to further review the possibilities on forming an ASEAN convention related to TIPs. This initiative was remained stagnant, until 2011 the Head of States/Government eventually reaffirmed the urgent need for the region to handling TIPs comprehensively through ASEAN Leaders' Joint Statement in Enhancing Cooperation against TIPs. In accordance with this joint statement, AMMTC held their $1^{\text {st }}$ Experts Meeting to Study the Feasibility of Developing ACTIP on July 2011 and followed by the $2^{\text {nd }}$ Experts Meeting to Study the Feasibility of Developing ACTIP on September the same year to examine the feasibility of the convention. On the $2^{\text {nd }}$ Meeting, Philippines offered the framework plan of ACTIP, while Indonesia came up with the concept paper of Proposed Agreement on Cooperation against TIPs in Southeast Asia which regulated about the establishment of a regional agreement on TIPs that bind all ASEAN member states. The formation of ACTIP was being held as Singapore and Thailand proposed a Regional Plan of Action (RPA, later named and ASEAN Plan of Action Against TIPs, Especially Women/ APA) through SOMTC Working Group on September 2012. Later, on April 2013, the $3^{\text {rd }}$ Experts Working Group on ACTIP was being arranged to continue the discussion of ACTIP. The preamble and first chapter of ACTIP were successfully formed at the $4^{\text {th }}$ Environmental Working Group (EWG) on ACTIP. The discussion of ACTIP article was going a bit slow as each article requires specific and elaborative consideration. ${ }^{24}$

On 2014, 5 meetings are being held. The continuous meetings within a year had faced some challenges as Singapore insisted on to put more attention to the RPA discussion. However, the preamble, General Provision, Use of Terms, Scope of Application, Criminalization and Law Enforcement, Protection of Sovereignty, and most chapters as well as articles associated with prevention, international cooperation, ratification, approval, and depository of ACTIP were successfully being discussed. After 9 meetings, Ad-Hoc Meeting (legal scrubbing) for the draft ACTIP and APA was being organized on April 2015 at Bogor to ensure the consistency of the text usage without changing the confirmed substances. After quite a long journey, ACTIP and APA were officially signed by all ASEAN member Head States/ Governments on $21^{\text {st }}$ November 2015 at the $27^{\text {th }}$ ASEAN High-Level Conference in the Kuala Lumpur. ${ }^{25}$

\section{The Relation Between ACTIP and APA}

\footnotetext{
${ }^{24}$ Ibid., pp.28-29.

${ }^{25}$ Ibid.
} 
The ASEAN Convention Against TIPs, Especially Women and Children (ACTIP) officially enters into force on $8^{\text {th }}$ March 2017 after The Philippines ratified it on $6^{\text {th }}$ February $2017 .{ }^{26}$ This provision aligns with the Article 29 of ACTIP which stated "This convention shall come into force on the thirtieth day following the deposit of the sixth instrument of ratification or approval with the Secretary-General of ASEAN in the respect to those parties that have submitted their instruments of ratification or approval." 27 The main purposes of this convention are to deter and fight TIPs, as well as ensure the effective and righteous punishment for the offenders; to defend and facilitate TIPs victims with thorough and highest consideration for their values based on the human rights principle; and to further enhance the cooperation and coordination among parties to achieve these purposes. ${ }^{28}$ ACTIP adopts the Palermo Protocol anti-trafficking framework based on the 3P's paradigms (Prosecution, Protection, and Prevention). To ensure its effectiveness, ACTIP will be monitored, reviewed, and reported periodically to the AMMTC by SOMTC. ${ }^{29}$ It will also be implemented alongside the APA. The Plan was basically being proposed in 2012 as a complementary to ACTIP as it is more action oriented. Since the proposal date, the two instruments had been inseparable and being discussed collectively.

The APA serves as a particular action plans within ASEAN Member States' national regulations, and pertinent global commitments, to completely and forcefully deliver regional obstaces common to all ASEAN Member States in the identified major concerns, to wit: prevention, protection of the victims, law enforcement and prosecution of the traffickers, and regional and international cooperation and coordination. ${ }^{30}$ APA also listed the common challenges among the ASEAN Countries in combatting the TIPs practice, such as officials' malfeasance and bureaucrats' corruptions, underdervelopment, social economic disparity, monetary imbalance, inadequate law enforcement and constitutional systems; the lack of capabilities of frontline officers to detect and prevent the movements of TIPs victims from source countries to transit, and designated countries; inappropriate legislation to effectively combat trafficking; improper victims' identification and provision to protect them; the ineffective regional regulation and other mechanism to enhance the international collaboration in eliminating TIPs, as well lack of cooperation between and relevant authorities. ${ }^{31}$ The challenges Indonesia face on

\footnotetext{
${ }^{26}$ ASEAN, ASEAN Welcomes Entry into Force of ACTIP, https://asean.org/asean-welcomesentry-into-force-of-actip/, 11 April 2019.

${ }^{27}$ Article 29 (a) ACTIP.

${ }^{28}$ Article 1(1) ACTIP.

${ }^{29}$ Article 24 of ACTIP.

${ }^{30}$ Chapter I Introduction APA.

${ }^{31}$ Chapter II Challenges APA.
} 
eradicating TIPs are somehow similar to the others ASEAN member countries as stated in the APA, namely poverty, lack of education and access to information, employment and/or economic opportunities ${ }^{32}$, such as low or inadequate salary, natural disasters, gender biases, high birthrate, geographical condition, as well as socio-cultural (the patrilineal inheritance system which has been deep-rooted in Indonesia cause discrimination and gender bias as this system position and value men higher than women).$^{33}$ The corrupt bureaucracy also contributes to the extensive TIPs practice in Indonesia. The unethical officials and elites are prone to support and defend the traffickers. The officials involve and play huge roles in the TIPs practice in Indonesia, exclusively at the border areas. For instance, in Entikong (the border area between Indonesia and Malaysia), lots of officers have been detected and found guilty due to their engagements with TIPs. ${ }^{34}$

The APA consists of 3 action plans that were quoted as "We, Member States of the ASEAN resolve to translate our political will into concrete actions by adopting a Plan of Action to 1) Strengthen the rule of border control among ASEAN Member States; 2) Intensify efforts to prosecute TIPs cases; 3) Strengthen regional cooperation based on shared responsibility to effectively address demand and supply that fosters all forms of TIPs, especially women and children, that leads to trafficking." This action plans being explained 4 sub-categories, as follows: ${ }^{35}$

a. Prevention of Trafficking in Persons by develop national data collection systems in relation with TIPs, utilize existing regional guidelines for the TIPs victims identification, increasing societies' awareness on TIPs through campaigns, seminars, workshops to maintain and educate public about TIPs modus operandi, enhancing the law enforcement procedures, immigration, labor, social welfare, and other related officials, adopt and implement proper regulations, conduct and support research studies on relevant topics in eradicating TIPs, ensure and put in place proper and effective mechanism (such as, proper border control mechanism, issuance of identity and travel documents), expand cross border cooperation and exchange and sharing data and information.

b. Protection of the Victims by guarantee administrative policies or domestic legal cover efforts to provide relevant information to victims of TIPs, in a

\footnotetext{
32 Prakorso Abdul Rahman and Nurmalinda Putri Ayu, "Kebijakan Hukum Terhadap Tindak Pidana Perdagangan Orang”, Seminar Nasional Hukum Universitas Negeri Semarang, 4 (1), (2017). p.8.

${ }^{33}$ Elfrida R Gultom, "Development of Women Position in The Patrilineal Inheritance of Indonesia Society", Jurnal Dinamika Hukum, 17 (2), (2017), p.196.

${ }^{34}$ Mahrus Ali and Bayu Aji Pramono, (2011), Perdagangan Orang: Dimensi, Instrumen Internasional Dan Pengaturannya di Indonesia, Bandung: Citra Aditya Bakti, p. 155.

${ }^{35}$ Chapter IV APA.
} 
language they understand, regarding their legal rights and the relevant court and administrative proceedings and facilitate their access to assistance in order to enable their views and concerns to be presented and considered at appropriate stages; provide specialized services to identified victims of TIPs, consistent with the ACTIP and other relevant international instruments, including access to health services; subject to domestic laws, rules, regulations and policies, and in appropriate cases, consider not holding victims of TIPs criminally; reaffirm the protection of human rights for all victims, continue the development of appropriate care, protection and support for victims of TIPs; ensure channels for victims of TIPs, particularly the child victims, to be supported with the physical, mental, social recovery and rehabilitation;

c. Law Enforcement and Prosecution of Crimes of TIPs by prosecute crimes of TIPs that encompass all forms of exploitation and enact, enforce and strengthen legislation that criminalizes all forms of TIPs; enact TIPs as a criminal offence; cultivate intense examination and investigation approaches to conduct surveillance and other pro-active methods to collect evidence and testimony from victim; improve attempts to investigate alleged matters of TIPs, encourage the tools to eliminate TIPs, prosecute the perpetrators, including through more efficient and systematic use of freezing assets; designate specialized officials personnel, such as prosecutors and set up prosecutorial specialized units that will handle trafficking in persons cases; combat and prosecute organized criminal groups engaged in TIPs, in accordance with domestic laws; investigate, interrogate, prosecute and punish corrupt government officials that enroll in or assist all kinds of TIPs and promote no tolerance policy against those corrupt officials; continue the development of suitable and effective protection mechanism for witnesses of TIPs; conduct capacity building, of law enforcers, labor inspectors, prosecutors, judges, immigration and foreign service officers, social welfare officers and other relevant personnel involved in combatting TIPs; reinforce the information-sharing, investigation and prosecution processes for cases of TIPs, including the setting up of specialized enforcement teams, encouraging joint enforcement between domestic agencies and fasttracking the investigation and prosecution of serious or aggravated cases, especially at the regional level.

d. Regional and International Cooperation and Coordination by intensify the Heads of Specialist Units (HSU) mechanism within ASEAN, the coordination and cooperation among ASEAN Member States in combatting crimes that might be connected with TIPs, and the operational cooperation between ASEAN Member States, in accordance with their domestic laws and bilateral or multilateral agreements, joint investigation 
teams; utilize existing international mechanisms, including INTERPOL tools and resources such as INTERPOL database; enhance capacity building activities for the purposes of improving the preparation and receiving of requests relating to mutual legal assistance, extradition and cross-border law enforcement cooperation; utilize international cooperation; enhance collaboration and coordination among the ASEAN platforms dedicated to facilitating cooperation among ASEAN Member States in combating TIPs; promote mutually beneficial collaboration with ASEAN Dialogue Partners and other relevant international, regional and sub-regional organizations to combat TIPs; identify focal points to facilitate communication, data sharing and exchange of information on trafficking in persons to strengthen prevention and protection policies and programmes among ASEAN Member States; promote cooperation and coordination among governmental institutions, civil society organisations, private sector, media, and all relevant stakeholders, to strengthen prevention and protection policies and programmes; enhance and continue the development of regional guidelines, in light of national and bilateral guidelines, to combat trafficking in persons by strengthening coordination partnership, and international cooperation and implement effectively the relevant existing guidelines.

\section{The Accommodation of ACTIP in Indonesian Regulation}

Indonesia ratified ACTIP 6 months after it entered into force on October 2017 and became the penultimate states to ratify the convention, leaving Brunei Darussalam. The implication to parties who ratified after the convention is being stated as "... In respect of a Party ratifying or approving the convention subsequent to its entry into force, it shall enter into force for the Party on the date its instrument of ratification or approval is deposited. ${ }^{36}$ " ACTIP is ratified through the Law No. 12/2017 concerning the Ratification of ASEAN Convention Against TIPs, Especially Women and Children. It basically consists of 7 Chapters and 31 Articles (distributed into Chapter II Criminalization/Article 5-10, Chapter III Prevention/Article 11-13, Chapter IV Protection/Article 14-15, Chapter V Law Enforcement/ Article 16-17, Chapter VI International Cooperation/ Article 19-22). Prior to the ratification of ACTIP, Indonesia already has several legislations related to TIPs. The provisions on the prohibition of TIPs are essentially instill in the Indonesian Criminal Code (Kitab Undang-Undang Pidana/KUHP) Article 297 which put forward the inhibition of TIPs, especially women and children and classifies such act as a criminal infringement, however this article charges such a lenient penalty which is uneven with the adversity imposed on TIPs victims.

${ }^{36}$ Article 29 (b) ACTIP. 
Besides the Penal Code, TIPs is specifically regulated in Indonesia through the Law of The Republic of Indonesia No 21/ 2007 Concerning the Eradication of The Criminal Act of Trafficking in Persons. The formation and enactment of this law are due to the fact that there was no legislation relating to TIPs that was effective in providing comprehensive and integrated legal basis to combat TIPs at that moment. However, TIPs has intensified into organized and non-organized crime with a broad scope, set out an acute menace to the people globally. It is also the manifestation of Indonesia desire to prevent and counter TIPs based upon the noble values, national purpose, and international commitment. To ensure and enhance its effectiveness, this Law entails the government to consign a certained allocation for the application of prevention guidelines, programs and for the management of TIP issues ${ }^{37}$ This law set a jail punishment of a minimum 1 year and a maximum of 15 years with a fine minimum 40 million Rupiah and maximum of 600 million Rupiah with the possibility of applicable sentence increased by $1 / 3$ if the act is committed against children. It consists of 9 Chapter and 67 Article (Chapter II; Article 2-18) and other criminal actions related to the criminal act of TIPs (Chapter III; Article 19-27), investigation, prosecution, and examination in a court proceeding (Chapter IV; Article 28-42), protection of witness and victims (Chapter V; Article 43-55), prevention and treatment (Chapter VI; Article 56-58), International Cooperation and Community Participation (Chapter VII; Article 59).

${ }^{37}$ ASEAN, (2008), Update and Supplement to the 2006 study: ASEAN Reponses to Trafficking in Persons: Ending Impunity for Traffickers and Securing Justice for Victims (2007), Jakarta: ASEAN Secretariat, p.9. 
Table 1.1. Comparison of the legal substance between ACTIP and Law No 21/ 2007 Concerning the Eradication of The Criminal Act of TIPs

\begin{tabular}{|c|c|c|c|}
\hline No. & & ACTIP & Law No $21 / 2007$ \\
\hline 1. & Use of Terms & $\begin{array}{l}\text { Covers the definition } \\
\text { of } 14 \text { Terms (TIPs; } \\
\text { The consent of victim } \\
\text { of TIPs; recruitment, } \\
\text { transportation, } \\
\text { transfer, harboring, or } \\
\text { receipt; child; victim; } \\
\text { organized group; } \\
\text { serious crime; } \\
\text { transnational crime; } \\
\text { public official; } \\
\text { property; proceeds of } \\
\text { crime; freezing; } \\
\text { confiscation; predicate } \\
\text { offence) }\end{array}$ & $\begin{array}{l}\text { Covers the definition of } \\
13 \text { Terms (TIP; } \\
\text { Criminal Act of TIPs; } \\
\text { Victim; Child; Corporate } \\
\text { Entity; Exploitation; } \\
\text { Sexual Exploitation; } \\
\text { Recruitment; Sending; } \\
\text { Force; Threat of Force; } \\
\text { Restitution) }\end{array}$ \\
\hline 2. & $\begin{array}{l}\text { Criminalization } \\
\text { In general, both } \\
\text { regulations do } \\
\text { criminalize the } \\
\text { act of } \\
\text { recruitment, } \\
\text { transferring, } \\
\text { harboring, } \\
\text { transporting, } \\
\text { and receiving } \\
\text { the victims of } \\
\text { TIPs as well as } \\
\text { the act that } \\
\text { cause a person } \\
\text { to suffer major } \\
\text { or serious } \\
\text { injury to death, } \\
\text { mental } \\
\text { disturbance, } \\
\text { exposed to life } \\
\text { contagious life- }\end{array}$ & $\begin{array}{l}\text { Criminalize the act of } \\
\text { the laundering of } \\
\text { proceeds of crime and } \\
\text { corruption as well as } \\
\text { death as a result of } \\
\text { suicide cause by the } \\
\text { TIPs offenders. }\end{array}$ & $\begin{array}{l}\text { Criminalize the act that } \\
\text { cause TIPs victims to be } \\
\text { pregnant as it recognizes } \\
\text { the unborn babies as the } \\
\text { victims as well. }\end{array}$ \\
\hline
\end{tabular}




\begin{tabular}{|c|c|c|c|}
\hline & $\begin{array}{l}\text { threatening } \\
\text { disease. }{ }^{38}\end{array}$ & & \\
\hline 3. & Offenders ${ }^{39}$ & $\begin{array}{l}\text { Accentuate on the } \\
\text { participation of the } \\
\text { organized } \\
\text { arranged criminal } \\
\text { association and the } \\
\text { involvement of the } \\
\text { public officials. }\end{array}$ & $\begin{array}{l}\text { Acknowledge the } \\
\text { involvement } \\
\text { corporate of } \\
\text { including legal and non- } \\
\text { legal entity and } \\
\text { organized group. }\end{array}$ \\
\hline 4. & Prevention $^{40}$ & $\begin{array}{l}\text { The parties shall } \\
\text { engage in preventive } \\
\text { and insitutive action, } \\
\text { such as conducting a } \\
\text { research or study on } \\
\text { TIPs, collecting } \\
\text { information, and } \\
\text { encourage mass or } \\
\text { public broadcast } \\
\text { campaigns, cooperate } \\
\text { with relevant } \\
\text { organizations, enhance } \\
\text { bilateral, regional, and } \\
\text { international promote } \\
\text { cooperation; prome } \\
\text { capacity building, and } \\
\text { conduct } \\
\text { programs that will } \\
\text { benefit to the } \\
\text { prevention of TIPs in } \\
\text { the region }\end{array}$ & $\begin{array}{l}\text { Head and provincial } \\
\text { governments have the } \\
\text { obligation to draft and } \\
\text { develop regualtions, } \\
\text { agendas, action plans, } \\
\text { and set aside allocation/ } \\
\text { budgets to prevent TIPs. } \\
\text { The government also has } \\
\text { the obligation to form a } \\
\text { Task Force. It also } \\
\text { encourages } \\
\text { communities and } \\
\text { organizations } \\
\text { participation. }\end{array}$ \\
\hline 5. & Protection $^{41}$ & $\begin{array}{l}\text { Widely covers the } \\
\text { victim protection, } \\
\text { including protecting } \\
\text { the privacy of the } \\
\text { victims, cooperate } \\
\text { with TIPs related } \\
\text { organizations ro } \\
\text { provide housing, }\end{array}$ & $\begin{array}{l}\text { Protect both victim and } \\
\text { witness of TIPs likewisw } \\
\text { in the Law No. } 13 \text { of } \\
2006 \text { regarding Witness } \\
\text { and Victim protection. } \\
\text { To the extent, it also } \\
\text { covers the TIPs victim } \\
\text { rights, whether being }\end{array}$ \\
\hline
\end{tabular}

\footnotetext{
${ }^{38}$ Compare Article 5 ACTIP to Article 7 Law No 21/2007.

${ }^{39}$ Compare Article 6 of ACTIP and Article 13 \& 16 of Law No. 21/2007.

${ }^{40}$ Compare Chapter III of ACTIP and Chapter VI of Law No.21/2007.

${ }^{41}$ Compare Chapter IV of ACTIP and Chapter V of Law No.21/2007 .
} 


\begin{tabular}{|c|c|c|c|}
\hline & & $\begin{array}{l}\text { counselling, medical, } \\
\text { mental, and material } \\
\text { assistance, } \\
\text { employment, } \\
\text { educational, and } \\
\text { training possibilities. } \\
\text { Also covers the return } \\
\text { and repatriation } \\
\text { guidelines, yet no } \\
\text { record on the witness } \\
\text { protection. }\end{array}$ & $\begin{array}{l}\text { trafficked within or } \\
\text { outside Indonesia to get } \\
\text { appropriate } \\
\text { rehabilitation, } \\
\text { repatriation, and receive } \\
\text { restitution. }\end{array}$ \\
\hline 6. & $\begin{array}{l}\text { Law } \\
\text { Enforcement }{ }^{42}\end{array}$ & $\begin{array}{l}\text { Each party shall } \\
\text { designate specialized } \\
\text { units or authorities } \\
\text { with appropriate skills } \\
\text { and knowledge on } \\
\text { TIPs to deal with the } \\
\text { law enforcement } \\
\text { process (investigating } \\
\text { and prosecuting the } \\
\text { traffickers). It is also } \\
\text { regulated about the } \\
\text { sequestration } \\
\text { possessions } \\
\text { ownerships, assets, } \\
\text { equipments, or other } \\
\text { instrumentalities and } \\
\text { propiertorships related } \\
\text { to the TIPs activity and } \\
\text { traffickers. }\end{array}$ & $\begin{array}{l}\text { The law enforcement } \\
\text { procedures generally } \\
\text { consist of investigation, } \\
\text { prosecution, and } \\
\text { examination. During the } \\
\text { investigation according } \\
\text { to the presence of } \\
\text { adequate and ample } \\
\text { initial evidences, the } \\
\text { investigators have rights } \\
\text { to keep record and } \\
\text { monitor telephones lines } \\
\text { or other means of } \\
\text { communication of the } \\
\text { suspects, as well as } \\
\text { freezing the assets. }\end{array}$ \\
\hline 7. & $\begin{array}{l}\text { International } \\
\text { Cooperation }\end{array}$ & $\begin{array}{l}\text { Encourage the mutual } \\
\text { legal assistance in } \\
\text { criminal matters } 44 \text {, } \\
\text { such as sharing } \\
\text { intelligence, data and } \\
\text { information; } \\
\text { extradition, }\end{array}$ & $\begin{array}{l}\text { Indonesia has the } \\
\text { responsibility to engage } \\
\text { in international } \\
\text { cooperation, collaborate } \\
\text { with other states whether } \\
\text { bilaterally, regionally, or } \\
\text { multilaterally. }\end{array}$ \\
\hline
\end{tabular}

${ }^{42}$ Compare Chapter V of ACTIP and Chapter IV of Law No.21/2007.

${ }^{43}$ Compare Chapter VI of ACTIP and Article 59 of Law No.21/2007.

${ }^{44}$ Indonesia has ratified the Law No 1/2006 concerning Mutual legal Assistence in Criminal Matters (Undang-Undang No. 1 Tahun 2006 tentang Bantuan Timbal Balik Dalam Masalah Pidana) and conducted MLTA with other countries. 


\begin{tabular}{|l|l|}
\hline & $\begin{array}{l}\text { cooperation in law } \\
\text { enforcement to } \\
\text { identify, assist, and } \\
\text { protect victims, as well } \\
\text { as prosecute the } \\
\text { perpetrators; } \\
\text { international for the } \\
\text { cooperation for the } \\
\text { purpose of then. } \\
\text { confiscation. }\end{array}$ \\
\hline
\end{tabular}

From the table comparison, it can be seen that either ACTIP or Law No. 21/2007 are generally focusing and issuing the same matters. The most breakthrough substances on ACTIP that make it somehow more comprehensive than the Law No. 21/2007 are the expansion of the government's authority to provide a legal foundation for the national and local forces to cooperate with other ASEAN countries and the articles that clearly accentuate on the criminalization of laundering of proceeds of crime and corruption. In addition to the Law No 21/2007, there are another regulations related to the eradication of TIPs in Indonesia, such as the Presidential Regulation No. 69/2008 on the Task Force for the Prevention and Control of Human Trafficking (Peraturan Presiden No. 69 Tahun 2008 tentang Gugus Tugas Pencegahan dan Penanganan Tindak Pidana Perdagangan Orang) and the Regulation of the Coordinating Ministry for Human Development and Cultural Affairs No. 2/2016 on the National Action Plan of the Eradication of The Criminal Act of Trafficking in Persons 2015-2019. (Peraturan Menteri Koordinator Bidang Pembangunan Manusia dan Kebudayaan Republik Indonesia No 2 Tahun 2016 Tentang Rencana Aksi Nasional Pemberantasan Tindak Pidana Perdagangan Orang 2015-2019/ RAN TPPO). The task force is a coordinating agency concerned with the prevention and handling of TIPs, particularly advocacy, socialization, job training, monitoring the progress of the implementation of victim protection in terms of rehabilitation, repatriation, and social reintegration, monitoring the progress of law enforcement, and implementing report and evaluation. ${ }^{45}$ While, the National Plan aims to enhance the prevention of TIPs practice, providing rehabilitation focusing on health and social service, repatriation, and social integration for the TIPs victims, fulfill and harmonize legislation concerning TIPs, ensure the law enforcement on protecting the victims and prosecuting the offenders, expanding the coordination and cooperation between task force, authorities

\footnotetext{
${ }^{45}$ Article 4 of the Presidential Regulation No. 69/2008 on the Task Force for the Prevention and Control of Human Trafficking.
} 
and officials on both national and international level. These objectives are being pursued by implementing strategies, such as perform socialization, assistance, policy making, advocacy, synchronize and harmonize national, ministerial, and provincial regulations, enhancing the law enforcement officers, planners, auditors, and legal drafters capacities, monitoring, and conduct an evaluation. ${ }^{46}$

\section{Conclusion}

The spirits of ACTIP has been manifested since the 1990s through its predecessors, such as ASEAN Declaration Against TIPs, especially Women and Children, the ASEAN Leaders' Joint Statement in Enhancing Cooperation against TIPs in Southeast Asia. To ensure its effectiveness, the convention is being implemented along with the APA. Before the ratification of ACTIP, Indonesia has enacted the 2007 anti-trafficking law that was specifically regulated about TIPs matters. In addition to the law, Indonesia has also established the Presidential Regulation No. 69.2008 on the Task Force for the Prevention and Control of Human Trafficking, and the Regulation of the Coordinating Ministry for Human Development and Cultural Affairs No. 2/2016 on the National Action Plan of the Eradication of The Criminal Act of TIPs 2015-2019. These regulations are well-associated with and support the substances regulated at both ACTIP and APA.

Following the ratification of ACTIP through the Law No. 12/2017, the author cannot identify any discernable legislation particularly form to eradicate TIPs. However, according to the explanation in the journal above, the author concluded that basically, the existing regulations in Indonesia have somehow sufficiently accommodated the ACTIP as those have covered quite many substances that listed and pictured in the convention. Although, the existing regulations have sufficiently accommodated ACTIP for the current circumstances, yet the author suggests government take more initiatives in accommodating the convention to extend its effectiveness, such as encourage the regional governments to establish provincial regulations specifically formed to eradicate TIPs as each province face unique challenges due to its circumstances. Moreover, the prescription of the stronger compliance mechanism is also needed to level up the benefits and functions of this convention.

\section{A. Book}

\section{Bibliography}

\footnotetext{
${ }^{46}$ Chapter II of the Regulation of the Coordinating Ministry for Human Development and Cultural Affairs No. 2/2016 on the National Action Plan of the Eradication of The Criminal Act of Trafficking in Persons 2015-2019.
} 
Ali, Mahrus and Pramono, Bayu Aji. (2011). Perdagangan Orang: Dimensi, Instrumen Internasional Dan Pengaturannya di Indonesia. Bandung: Citra Aditya Bakti.

Nuraeny, Henny. (2011). Tindak Pidana Perdagangan Orang Kebijakan Hukum Pidana dan Pencegahannya. Jakarta: Sinar Grafika.

Pauline David, Fiona David, and Anne Gallagher. (2010). ASEAN Handbook on International Legal Cooperation in Trafficking in Persons Cases. Jakarta: ASEAN Secretariat.

\section{B. Journal and Article:}

Absor Ulli M., "Human Trafficking and The Challenges for Social Development in Indonesia", Jurnal Pemikiran Sosiologi, 5(1), (2019). https://doi.org/10.22146/jps.v5i1.35401.

Gultom Elfrida R., "Development of Women Position in The Patrilineal Inheritance of Indonesia Society", Jurnal Dinamika Hukum, 17 (2), (2017). http://dx.doi.org/10.20884/1.jdh.2017.17.2.886.

Mokhammad Najih, "Indonesian Penal Policy: Toward Indonesian Criminal Law Reform Based on Pancasila", Journal of Indonesian Legal Studies, 03(2), (2018).

Prakorso Abdul Rahman and Nurmalinda Putri Ayu, "Kebijakan Hukum Terhadap Tindak Pidana Perdagangan Orang", Seminar Nasional Hukum Universitas Negeri Semarang, 4(1), (2017).

Trajano Julius Cesar, "Combating Human Trafficking in East Asia: Mind the Gaps", NTS Insight Singapore, iN18-05, (2018).

\section{Report}

ASEAN, (2008), Update and Supplement to the 2006 study: ASEAN Reponses to Trafficking in Persons: Ending Impunity for Traffickers and Securing Justice for Victims (2007), Jakarta: ASEAN Secretariat.

ASEAN, (2012), ASEAN Documents on Combating Transnational Crime and Terrorism, Jakarta: ASEAN Secretariat.

ASEAN, (2016), ASEAN Political-Security Community Blueprint 2025, Jakarta: ASEAN Secretariat.

ILO and Walk Free Foundation, (2017), Global Estimates of Modern Slavery, Geneva: International Labor Office.

IOM Local X and USAID, (2018), Human Trafficking Snapshot Indonesia, Jakarta: IOM Stop Exploitation.

Kementerian Hukum dan HAM Republik Indonesia, (2016), Naskah Akademis RUU Tentang Pengesahan ACTIP, Jakarta: Kementerian Hukum dan HAM RI.

Sekertariat GT-PPTPPO, (2015), Pencegahan dan Penanganan Tindak Pidana Perdagangan Orang Laporan 2015, Indonesia: Kementrian 
Pemberdayaan dan Perlindungan Perempuan dan Anak Republik Indonesia.

UNODC. (2008). Toolkit to Combat Trafficking in Persons Global Programme Against Trafficking in Human Beings. Vienna: UNODC Office.

\section{World Wide Web}

Akbar, Norvan, Indonesia Meratifikasi Konvensi ASEAN Anti-Perdagangan Orang, https://jpp.go.id/polkam/hukum/311972-indonesiameratifikasi-konvensi-anti-perdagangan-orang-asean , 11 April 2019.

ASEAN, ASEAN Welcomes Entry into Force of ACTIP, https://asean.org/asean-welcomes-entry-into-force-of-actip/, 11 April 2019.

ASEAN, ASEAN Declaration on Transnational Crime Manila, 20 December 1997, https://asean.org/?static_post=asean-declaration-ontransnational-crime-manila-20-december-1997, 31 May 2019.

\section{E. Legislation}

Indonesian Penal Code.

Law of The Republic of Indonesia No 21/ 2007 Concerning the Eradication of The Criminal Act of Trafficking in Persons.

Regulation of the Coordinating Ministry for Human Development and Cultural Affairs No. 2/2016 on the National Action Plan of the Eradication of The Criminal Act of Trafficking in Persons 2015-2019.

Presidential Regulation No. 69/2008 on the Task Force for the Prevention and Control of Human Trafficking.

ASEAN Convention Against Trafficking in Persons, Especially Women and Children.

ASEAN Plan of Action Against Trafficking in Persons, Especially Women ASEAN Declaration Against Trafficking in Persons, Particularly Women and Children. 